OPEN ACCESS

Edited by:

Steffen Kolb,

Leibniz Center for Agricultural

Landscape Research

(ZALF), Germany

Reviewed by:

Yong Li,

Zhejiang University, China

Matthias Noll,

Hochschule Coburg, Germany

*Correspondence:

Wei Ding

dwing818@163.com

Specialty section:

This article was submitted to

Terrestrial Microbiology,

a section of the journal

Frontiers in Microbiology

Received: 05 June 2020 Accepted: 02 November 2020 Published: 30 November 2020

Citation

Zhang S, Jiang Q, Liu X, Liu L and

Ding W (2020) Plant Growth

Promoting Rhizobacteria Alleviate

Aluminum Toxicity and Ginger Bacterial Wilt in Acidic Continuous

Cropping Soil.

Front. Microbiol. 11:569512.

doi: $10.3389 /$ fmicb.2020.569512

\section{Plant Growth Promoting} Rhizobacteria Alleviate Aluminum Toxicity and Ginger Bacterial Wilt in Acidic Continuous Cropping Soil

\author{
Shuting Zhang, Qipeng Jiang, Xiaojiao Liu, Liehua Liu and Wei Ding* \\ College of Plant Protection, Southwest University, Chongqing, China
}

Long-term monoculture cropping is usually accompanied by soil acidification and microbial community shifts. Soil aluminum ions are dissolved under acidic condition ( $\mathrm{pH}<5.0$ ), and the resulting aluminum bioavailability can cause toxic effects in plants. In this study, we investigated the bacterial community compositions and aluminum toxicity in fields monocultured with ginger for 35 years, 15 years, and 1 year. Within these fields are ginger plants without and with ginger bacterial wilt disease. The results confirmed that the degree of aluminum toxicity in the diseased soil was more severe than that in the healthy soil. Continuous cropping can significantly increase the bacterial diversity and change the bacterial community composition of ginger rhizosphere soil. The relative abundance of plant growth-promoting rhizobacteria (PGPRs) was increased in the soils used for the continuous cropping of ginger. Additionally, aluminum toxicity had a significant positive correlation with Bacillus, Pseudomonas, Arthrobacter, and Serratia in healthy soils. Based on these results, aluminum stress may stimulate the increase of PGPRs (Bacillus, Pseudomonas, Arthrobacter, and Serratia), thereby alleviating ginger aluminum toxicity and bacterial wilt in extremely acidic soil $(\mathrm{pH}<4.5)$.

\footnotetext{
Keywords: continuous cropping, aluminum toxicity, extremely acidic soil, ginger bacterial wilt, plant growth promoting rhizobacteria (PGPR)
}

\section{INTRODUCTION}

Continuous cropping refers to growing the same crop in the same soil year after year (Shipton, 1977). Long-term continuous cropping usually enriches soil-borne pathogens, leading to yield declines (Liu et al., 2014b). Continuous cropping is also closely related to the occurrence of bacterial wilt (She et al., 2016).

Soil acidification is a serious global environmental problem of economic concern that limits the sustainable development of modern agriculture, and soil acidification $(\mathrm{pH} 4.5-5.5)$ aggravates the occurrence of tobacco bacterial wilt (Li et al., 2017; Singh et al., 2017). At slightly acidic or neutral soil $\mathrm{pH}$ values, Aluminum ( $\mathrm{Al}$ ) occurs primarily in the form of insoluble aluminosilicates or oxides. With the decrease of the $\mathrm{pH}$, dissolved aluminum increased in the soil (Kochian, 1995). The effect of the $\mathrm{pH}$ on the dissolution of aluminum varies with the soil type. At $\mathrm{pH}$ values below 5, large amounts of aluminum ions are dissolved from clay minerals (Baba and Okazaki, 2000; Kochian et al., 2015). When $\mathrm{pH}$ values are below 4.5, the dissolution of aluminum in three acidic soils followed the order of red soil $>$ lateritic red soil $>$ latosol (Xu and Ji, 1998). 
Aluminum has a wide range of toxic effects on plants. Aluminum ions first inhibit root cell expansion and elongation; however, over the longer term, cell division is also inhibited, thereby inhibiting root growth (Kochian et al., 2015). Moreover, aluminum can alter the usual functions of the plasma membrane by inducing membrane lipid peroxidation (Massot et al., 1999; Vitorello et al., 2005), inducing imbalances in the uptake and acquisition of various mineral elements, such as $\mathrm{Ca}, \mathrm{Mg}$, and $\mathrm{P}$ (Olivares et al., 2009; Silva et al., 2012). Aluminum (Al) toxicity is a primary factor in the reduction of crop yields in acidic soils (Kochian et al., 2015).

There are many forms of aluminum in acidic soils, and the toxic effects of the different forms of $\mathrm{Al}$ (speciation) on plant growth diminish in the following order: $\mathrm{Al}^{3+}, \mathrm{Al}(\mathrm{OH})^{2+}$, $\mathrm{Al}(\mathrm{OH})_{2}^{+}$, and $\mathrm{Al}(\mathrm{OH})_{4}^{-}$(Bojorquez-Quintal et al., 2017). However, $\mathrm{Al}^{3+}$ is considered the most toxic to plant among all the forms of aluminum (Schmitt et al., 2016). Therefore, the concentration of aluminum ions is an important indicator for evaluating plant aluminum toxicity (Rehmus et al., 2014). Soil acidification causes pronounced changes in the soil chemistry, such as the dissolution and release of $\mathrm{Al}, \mathrm{Mn}$, and $\mathrm{Fe}$, the depletion of $\mathrm{Mg}^{2+}$ and $\mathrm{Ca}^{2+}$ and deficiencies of phosphorous (Kochian et al., 2004). During the decomposition process of acidic organic groups in litter, ecologically and physiologically essential $\mathrm{Ca}^{2+}$ or acidic cations such as $\mathrm{Al}^{3+}$ and $\mathrm{Fe}^{3+}$ show signs of toxicity (Luo, 2000). Therefore, using $\mathrm{Ca}^{2+} / \mathrm{Al}^{3+}, \mathrm{Mg}^{2+} / \mathrm{Al}^{3+}$, and $\mathrm{Ca}^{2+} /\left(\mathrm{Ca}^{2+}+\mathrm{Fe}^{3+}+\mathrm{Al}^{3+}\right)$ to assess aluminum toxicity is better than only using the absolute concentrations of $\mathrm{Al}^{3+}$ (Kazda and Zvacek, 1989; Wit et al., 2001; Liu et al., 2014a).

Microorganisms play an indispensable role in maintaining soil health (Bruggen and Semenov, 2000). Continuous cropping influences tobacco bacterial wilt by affecting the soil microbial community composition and structure (She et al., 2016). The soil $\mathrm{pH}$ is the main predictor of soil bacterial community changes, and the soil $\mathrm{pH}$ has a strong influence on the relative abundance and diversity of bacteria (Rousk et al., 2010; Zhalnina et al., 2015). However, the role of aluminum ions in influencing the microbial community composition in acidic soil is still unclear.

In response to plant stresses, many microorganisms increase in number or proportion (Liu et al., 2020a), as is the case for plant growth-promoting rhizobacteria (PGPRs), which have the potential to improve crop production under different stress conditions alone and/or in combination with other microbes (Nadeem et al., 2015). Under stress conditions, PGPRs are beneficial through particular mechanisms, such as regulating nutrient uptake (Raj et al., 2003), inducing systemic resistance (Choudhary et al., 2007), and preventing disease (Guo et al., 2004) and aluminum stress (Labanca et al., 2020; Shi et al., 2020). Some of these PGPRs belong to important genera, including Bacillus, Paenibacillus, Pseudomonas, Serratia, Arthrobacter, Azospirillum, Burkholderia, Streptomyces, and Flavobacterium, among others (Lugtenberg and Kamilova, 2009; Niu et al., 2011; Nadeem et al., 2015). Strains belonging to Bacillus, Pseudomonas, Streptomyces, and Serratia have been used as PGPRs for ginger growth promotion and biocontrol studies (Tahat and Kamaruzaman, 2010; Dinesh et al., 2015).
Ginger (Zingiber officinale Roscoe) is one of the most economically valuable plants and is used worldwide as a spice and flavoring agent (Li et al., 2018). Ginger bacterial wilt, which is caused by Ralstonia solanacearum, is an important soil-borne disease of ginger (Ming et al., 2005). Ginger is an extremely acid-tolerant species with a minimum $\mathrm{pH}$ tolerance of 3.3 (Islam et al., 1980). Soil with a $\mathrm{pH}$ value below 4.5 is considered extremely acidic soil (Zhou et al., 2011). According to our survey, in Rongchang, Chongqing, ginger is planted in a continuous mono-cropping pattern, and the soil is extremely acidic $(\mathrm{pH}<4.5)$. Ginger bacterial wilt is a widespread soilborne disease in this area. Nonetheless, the ginger in some areas is still healthy after continuous mono-cropping for over 15 years. In this study, we collected soil without bacterial wilt, which was referred to as "healthy" soil, from areas with 35 years $(35 \mathrm{H}), 15$ years $(15 \mathrm{H})$, and 1 year $(1 \mathrm{H})$ of continuous cropping. The soil with bacterial wilt was referred to as "diseased" soil and was collected from areas with 35 years (35D) and 15 years (15D) of continuous cropping. We analyzed the index of aluminum toxicity values and the bacterial community composition of the samples. We hypothesized that (i) aluminum ions influence the occurrence of ginger bacterial wilt under extreme acidification conditions and (ii) PGPRs, such as Bacillus and Pseudomonas, play an important role in overcoming continuous monocropping obstacles under aluminum toxicity stress. Specifically, this study aimed to determine the reason why ginger bacterial wilt varies in occurrence in extremely acidic continuous cropping soil.

\section{MATERIALS AND METHODS}

\section{Soil Sampling}

Soil sample were collected from an agricultural field site owned by the Changling farm in Rongchang, Chongqing city, China $\left(29^{\circ} 30^{\prime} 6.50^{\prime \prime} \mathrm{N}, 105^{\circ} 22^{\prime} 41.13^{\prime \prime} \mathrm{E}\right)$. The tested soil has been classified as clay. According to the survey, the incidence of bacterial wilt with 35 and 15 years of continuous cropping was 5 and $53 \%$, respectively. We chose the long-term continuous monoculture fields with ginger wilt as diseased soil (continuous cropping for 35 years, 35D, and continuous cropping for 15 years, 15D), whereas sites without disease were treated as healthy soil (continuous cropping for 35 years, $35 \mathrm{H}$, continuous cropping for 15 years, $15 \mathrm{H}$, and 1 year, $1 \mathrm{H})$. The $35 \mathrm{H}, 35 \mathrm{D}, 15 \mathrm{H}$, and $15 \mathrm{D}$ soils were collected in August 2014. The $1 \mathrm{H}$ soil was collected in June 2015. The distance between each sampling point was within $100 \mathrm{~m}$, and the ecological environment was consistent. We pulled out the ginger plants and then collected the soil attached to the roots as the rhizosphere soil. Five ginger plants were randomly selected, and the rhizosphere soil was collected and mixed into one sample as a replicate, with three replicates collected for each treatment. The soil samples were transported to the laboratory at $4^{\circ} \mathrm{C}$ and then stored at $-40^{\circ} \mathrm{C}$ before DNA extraction.

\section{Soil Chemical Properties}

The soil $\mathrm{pH}$ was measured at a soil/water ratio of $1 / 2.5$ (weight/volume). The air-dried soil $(10 \mathrm{~g}, 2 \mathrm{~mm})$ and $25 \mathrm{~mL}$ of deionized water were shaken together for $5 \mathrm{~min}$ and left to settle for $30 \mathrm{~min}$, after which the $\mathrm{pH}$ was determined with 
TABLE 1 | Aluminum toxicity index of different samples.

\begin{tabular}{|c|c|c|c|c|c|c|c|c|}
\hline Treatment & $\mathrm{pH}$ & ExAl (mg/kg) & AvaFe (mg/kg) & $\begin{array}{c}\text { ExMg } \\
\text { (mg/kg) }\end{array}$ & $\mathrm{ExCa}(\mathrm{mg} / \mathrm{kg})$ & $\mathrm{Ca}^{2+} / \mathrm{Al}^{3}$ & $\mathrm{Mg}^{2+} / \mathrm{Al}^{3+}$ & $\begin{array}{c}\mathrm{Ca}^{2+} / \\
\left(\mathrm{Ca}^{2+}+\mathrm{Fe}^{3+}+\right. \\
\left.\mathrm{Al}^{3+}\right)\end{array}$ \\
\hline $35 \mathrm{H}$ & $3.96 \pm 0.02 a$ & $438.02 \pm 24.01 c$ & $42.04 \pm 0.05 d$ & $155.50 \pm 2.28 b$ & $454.37 \pm 89.66 b$ & $1.03 \pm 0.19 a b$ & $0.36 \pm 0.02 b$ & $0.48 \pm 0.04 b$ \\
\hline 35D & $4.05 \pm 0.01 \mathrm{ab}$ & $385.00 \pm 16.77 \mathrm{bc}$ & $42.88 \pm 0.06 e$ & $109.62 \pm 3.64 a$ & $185.12 \pm 8.12 \mathrm{a}$ & $0.48 \pm 0.03 a$ & $0.29 \pm 0.02 a$ & $0.30 \pm 0.01 a$ \\
\hline $15 \mathrm{H}$ & $4.22 \pm 0.01 b c$ & $337.30 \pm 10.17 a b$ & $39.85 \pm 0.06 b$ & $374.37 \pm 4.05 c$ & $1184.12 \pm 74.42 c$ & $3.50 \pm 0.12 c$ & $1.11 \pm 0.03 d$ & $0.76 \pm 0.01 d$ \\
\hline $15 \mathrm{D}$ & $4.41 \pm 0.00 c$ & $299.05 \pm 0.80 a$ & $40.86 \pm 0.05 c$ & $191.25 \pm 8.54 b$ & $526.87 \pm 14.19 b$ & $1.76 \pm 0.05 b$ & $0.64 \pm 0.03 c$ & $0.61 \pm 0.01 c$ \\
\hline $1 \mathrm{H}$ & $4.26 \pm 0.10 \mathrm{bc}$ & $334.09 \pm 23.86 a b$ & $6.32 \pm 0.36 a$ & $394.67 \pm 13.82 c$ & $1949.96 \pm 31.33 d$ & $5.89 \pm 0.36 d$ & $1.19 \pm 0.08 d$ & $0.85 \pm 0.01 d$ \\
\hline
\end{tabular}

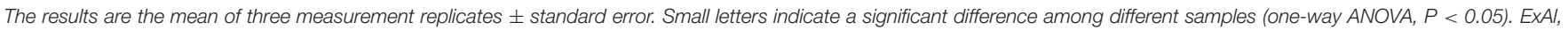
exchangeable aluminum; AvaFe, available iron; ExMg, exchangeable magnesium; ExCa, Exchangeable calcium.

a $\mathrm{pH}$ electrode (InLab Science, Mettler Toledo, Switzerland) (Pietri and Brookes, 2008). The soil exchangeable aluminum ions were extracted with $1 \mathrm{~mol} / \mathrm{L} \mathrm{KCl}$ and then calibrated with $0.02 \mathrm{~mol} / \mathrm{L} \mathrm{NaOH}$. The available iron, exchangeable magnesium, exchangeable calcium, and other basic chemical properties of each soil sample were determined using standard methods in the soil analysis laboratory of Southwest University, China (Supplementary Table 1). The aluminum ion concentration, $\mathrm{Ca}^{2+} / \mathrm{Al}^{3+}, \mathrm{Mg}^{2+} / \mathrm{Al}^{3+}$, and $\mathrm{Ca}^{2+} /\left(\mathrm{Ca}^{2+}+\mathrm{Fe}^{3+}+\mathrm{Al}^{3+}\right)$ were used as indicators for evaluating aluminum toxicity (Kazda and Zvacek, 1989; Wit et al., 2001; Liu et al., 2014a; Rehmus et al., 2014).

\section{DNA Extraction and Sequencing Library Construction}

The total genomic DNA was extracted from $0.5 \mathrm{~g}$ of soil using the Omega Biotek Soil DNA kit (Omega Biotek, USA), by following the standard protocol. PCR amplifications were conducted with 338 forward primers (5'-ACTCCTACGGGAGGCAGCAG-3') and 806 reverse primers ( $5^{\prime}$-GGACTACHVGGGTWTCTAAT$3^{\prime}$ ), which amplified the $\mathrm{V} 3-\mathrm{V} 4$ region of the $16 \mathrm{~S}$ rRNA gene (Xu et al., 2016).

The PCR amplification and sequencing library construction were performed in accordance with the procedures described by Zhang S. et al. (2017). The raw sequence analysis was performed using the Illumina MiSeq paired end $250 \mathrm{bp}$ protocol (Illumina, Inc., San Diego, CA, USA) at the Center for Genomic Research, Shanghai Majorbio Biotechnology Co. Ltd, China. In total, 394,283 sequences were obtained from the 15 samples through 16S rRNA high-throughput sequencing analysis. The average read length was $434 \mathrm{bp}$. The raw reads were deposited into the NCBI short-reads archive database under accession number SRP224758.

\section{Statistical Analysis}

The Raw Illumina FASTQ files were processed in QIIME v1.7.0 (Quantitative Insights Into Microbial Ecology) (Caporaso et al., 2010). The operational taxonomic units (OTUs) were identified based on a threshold of 97\% pairwise identity by QIIME.

The bacterial community data was analyzed on the free online Majorbio Cloud Platform (http://www.i-sanger.com/). To examine the effects of the number of continuous cropping years and disease on the microbial community structures, nonmetric multidimensional scaling (NMDS) and PERMANOVA (Permutational Multivariate Analysis Of Variance) based on the unweighted UniFrac distance were conducted with corresponding function in the "vegan" package in the $\mathrm{R}$ environment. The selection of PGPRs referred to Nadeem et al. (2015). The relative abundances of PGPRs were multiplied by 100,000 and then LOG10 values were calculated. The figures were created using Origin 9.0 software and GraphPad Prism 8.0.1. The mean and standard error for each set of data were calculated by one-way analysis of variance (ANOVA) with Tukey's honest significant difference test $(P<0.05)$ using SPSS software (version 17.0). The correlations between aluminum ions, $\mathrm{Ca}^{2+} / \mathrm{Al}^{3+}, \mathrm{Mg}^{2+} / \mathrm{Al}^{3+}$ and $\mathrm{Ca}^{2+} /\left(\mathrm{Ca}^{2+}+\mathrm{Fe}^{3+}+\mathrm{Al}^{3+}\right)$, and PGPRs were analyzed by Spearman analysis using SPSS software (version 17.0).

\section{RESULTS}

\section{Aluminum Toxicity Was More Severe in Diseased Soil}

The $\mathrm{pH}$ values of all the soil samples were below 4.5, with that of $15 \mathrm{D}$ being the highest $(\mathrm{pH}=4.41)$ and that of $35 \mathrm{H}$ being the lowest $(\mathrm{pH}=3.96)$. With the increase in continuous cropping years, the soil $\mathrm{pH}$ decreased. Additionally, the concentrations of exchangeable aluminum and available iron significantly increased; however, the concentrations of exchangeable magnesium and exchangeable calcium and the rates of $\mathrm{Ca}^{2+} / \mathrm{Al}^{3+}, \mathrm{Mg}^{2+} / \mathrm{Al}^{3+}$, and $\mathrm{Ca}^{2+} /\left(\mathrm{Ca}^{2+}+\mathrm{Fe}^{3+}+\mathrm{Al}^{3+}\right)$ significantly decreased $(P<0.05)$. The concentration of exchangeable magnesium and exchangeable calcium and the rate of $\mathrm{Ca}^{2+} / \mathrm{Al}^{3+}, \mathrm{Mg}^{2+} / \mathrm{Al}^{3+}$, and $\mathrm{Ca}^{2+} /\left(\mathrm{Ca}^{2+}+\mathrm{Fe}^{3+}+\mathrm{Al}^{3+}\right)$ in healthy soil were significantly higher than those in diseased soil $(P<0.05$, Table 1$)$.

\section{Continuous Cropping Changed the Bacterial Community Structure}

The rarefaction curves are illustrated in Supplementary Figure 1. The continuous-cropping samples showed increased Shannon index values and significantly reduced Simpson values $(P<0.05$, Supplementary Figure 2$)$. This indicated that continuous cropping significantly increased 

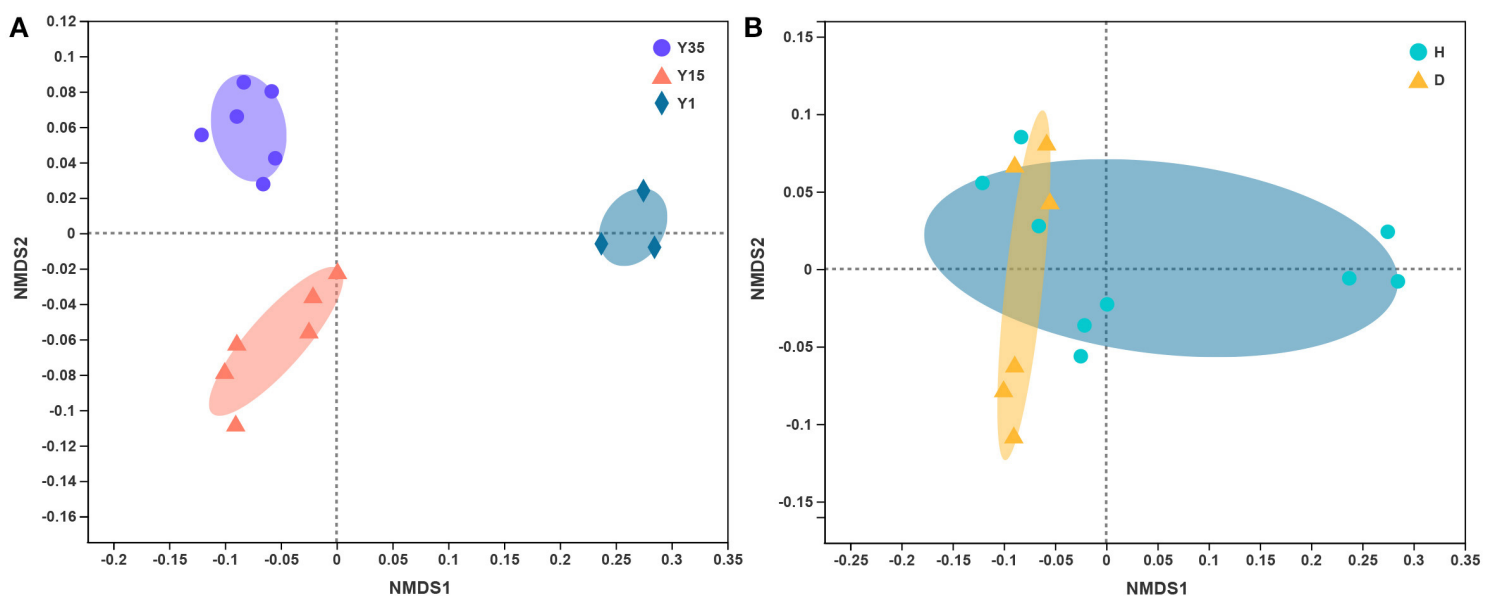

FIGURE 1 | Non-metric multidimensional scaling (NMDS) of the unweighted UniFrac analysis based on the OTU level. (A) Grouped by continuous cropping years (pseudo-F: 7.005, $R^{2}=0.539, P=0.001$, PERMANOVA). (B) Grouped by healthy and diseased. (pseudo-F: $2.491, R^{2}=0.161, P=0.038$, PERMANOVA). Y35-continuous cropping for 35 years, $\mathrm{Y} 15$-continuous cropping for 15 years, $\mathrm{Y} 1$-one year; $\mathrm{H}$ - the heathy soil without bacterial wilt, $\mathrm{D}-$ diseased soil with bacterial wilt.

the diversity of soil microbes. There was no significant difference in the microbial richness among the different treatments (Supplementary Figure 2).

The composition of the bacterial community changed significantly among different continuous cropping years, as visualized in the NMDS ordination (Figure 1A), resulting in a two-dimensional final solution with a stress value of 0.056 . The PERMANOVA analysis revealed that the difference was statistically supported $\left(P\right.$-value $=0.001$, pseudo-F $=22.147, \mathrm{R}^{2}$ $=0.788)$. However, there was no significant distinction between the diseased and healthy soil $(P$-value $=0.073$, pseudo-F $=2.413$, $\mathrm{R}^{2}=0.156$, using PERMANOVA, Figure 1B).

The distribution of the bacterial groups at the phylum level is shown in Figure 2. The relative abundance of Proteobacteria in $1 \mathrm{H}$ was significantly higher $(P<0.05)$ than those in the other groups. Upon comparing $35 \mathrm{H}$ with $1 \mathrm{H}$, the Planctomycetes group was significantly higher, while the Bacteroidetes was significantly lower $(P<0.05)$. The relative abundances of Patescibacteria and WPS-2 in $15 \mathrm{H}$ were significantly higher than those in 15D. However, the trend of the Gemmatimonadetes abundance was the exact opposite. There was no significant difference in the bacterial community composition at the phylum level between the diseased and healthy soil after 35 years of continuous cropping. The relative abundance of Ralstonia, which the genus of the ginger bacterial wilt pathogen, was higher in diseased soil than in healthy soil (Supplementary Figure 3). Among the samples, 15D had the highest relative abundance of Ralstonia, which was significantly higher than those in $1 \mathrm{H}(P=$ $0.0017), 15 \mathrm{H}(P=0.0154)$, and $35 \mathrm{H}(P=0.0028)$, respectively.

\section{Aluminum Stress Stimulated Plant Growth-Promoting Rhizobacteria Enrichment}

Compared with $1 \mathrm{H}$, the relative abundance of PGPRs, such as Pseudomonas, Bacillus, Serratia, and Arthrobacter, was increased in the rhizosphere soils of long-term continuous-cropping areas (Figure 3). There was a significant decrease in the relative abundance of Paenibacillus after long-term continuous cropping. Interestingly, Bacillus had an extremely significantly positive correlation (Spearman, $r=0.670, P=0.006$ ) with aluminum ions in all soil samples. However, $\mathrm{Ca}^{2+} / \mathrm{Al}^{3+}, \mathrm{Mg}^{2+} / \mathrm{Al}^{3+}$, and $\mathrm{Ca}^{2+} /\left(\mathrm{Ca}^{2+}+\mathrm{Fe}^{3+}+\mathrm{Al}^{3+}\right)$ had extremely significantly negative correlation with Pseudomonas, Bacillus, Arthrobacter, and Serratia (Supplementary Table 2). Furthermore, aluminum ions had significantly positive correlations with Pseudomonas and Bacillus in healthy soils. $\mathrm{Ca}^{2+} / \mathrm{Al}^{3+}, \mathrm{Mg}^{2+} / \mathrm{Al}^{3+}$, and $\mathrm{Ca}^{2+} /\left(\mathrm{Ca}^{2+}+\mathrm{Fe}^{3+}+\mathrm{Al}^{3+}\right)$ had extremely significantly negative correlations with Pseudomonas, Bacillus, Arthrobacter, and Serratia in healthy soil (Table 2).

\section{DISCUSSION}

\section{Continuous Cropping Aggravates the Degree of Aluminum Toxicity and Increases the Occurrence of Bacterial Wilt}

The soil $\mathrm{pH}$ has a very significant negative correlation with exchangeable aluminum ions (Dong et al., 1999; Xu et al., 2014). By raising the soil $\mathrm{pH}$ and $\mathrm{Ca}$ content, reducing the aluminum ion concentration can effectively control bacterial wilt ( $\mathrm{Li}$ and Dong, 2013). In this study, the $\mathrm{pH}$ range of the ginger soil sample was between 3.96 and 4.41 (Table 1), which is suitable for the growth of ginger (Islam et al., 1980). As the continuous cropping years increased, $\mathrm{Ca}^{2+} / \mathrm{Al}^{3+}, \mathrm{Mg}^{2+} / \mathrm{Al}^{3+}$, and $\mathrm{Ca}^{2+} /\left(\mathrm{Ca}^{2+}+\mathrm{Fe}^{3+}+\mathrm{Al}^{3+}\right)$ in the healthy soils significantly declined. This indicated that the soil aluminum toxicity worsened with the increase in the number of continuous cropping years. Although the concentration of exchangeable aluminum in the healthy soil was higher than that in the diseased soil, the rates of $\mathrm{Mg}^{2+} / \mathrm{Al}^{3+}, \mathrm{Ca}^{2+} / \mathrm{Al}^{3+}$, and $\mathrm{Ca}^{2+} /\left(\mathrm{Ca}^{2+}+\mathrm{Fe}^{3+}+\mathrm{Al}^{3+}\right)$ in the healthy soils were also higher than those in the diseased soil. This 


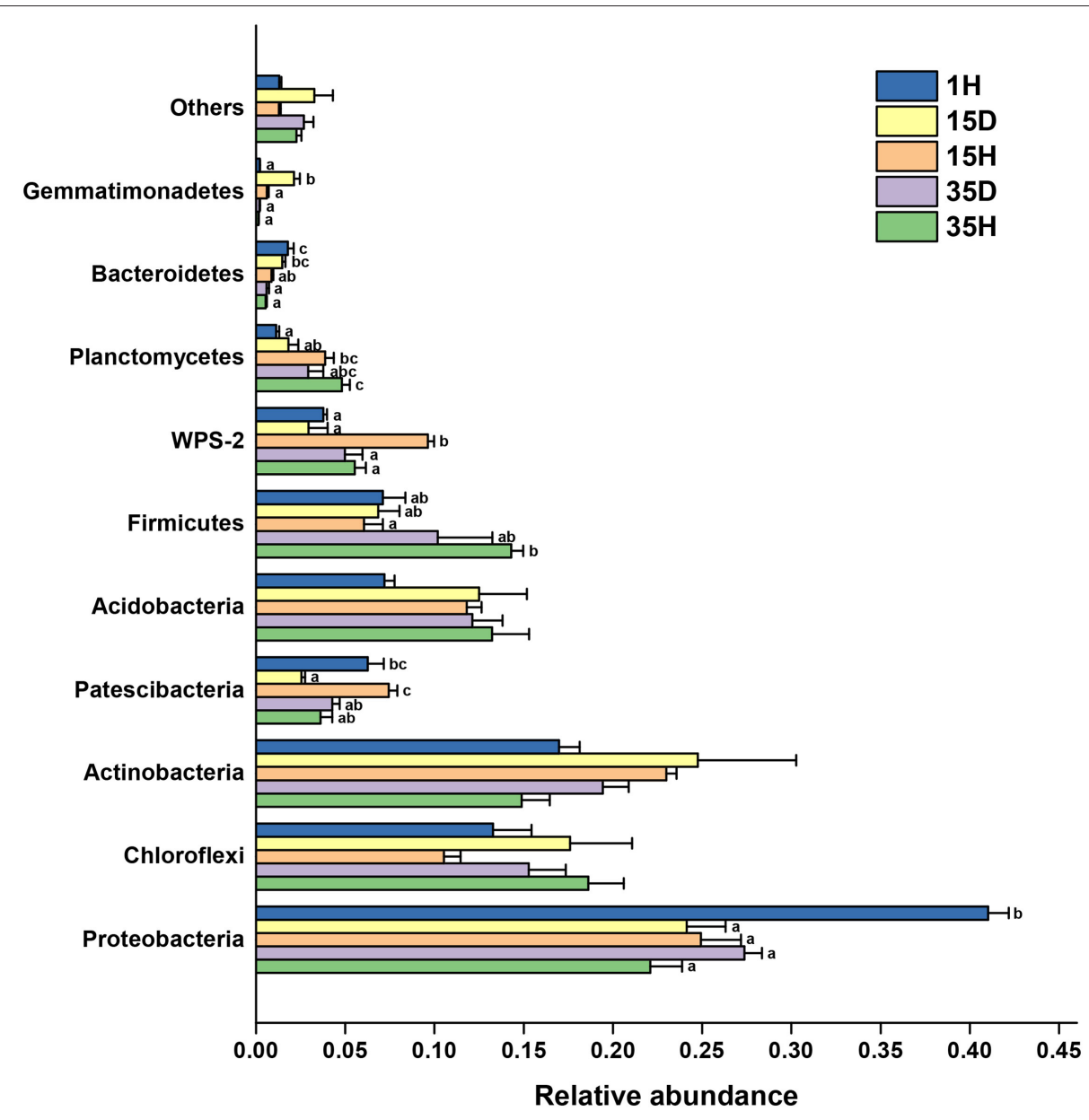

FIGURE 2 | The relative abundance of the main phyla in the soil samples $(n=3)$. Different letters indicate significant differences based on one-way ANOVA (Turkey test) at $P<0.05$.

result indicated that the aluminum toxicity in the diseased soil was more serious than that in the healthy soil. The degree of aluminum toxicity in ginger cropping areas may be a key factor affecting the occurrence of ginger bacterial wilt in extremely acidic soil environments.

\section{Continuous Cropping Increased the Bacterial Diversity and Changed the Bacterial Community Structure}

The bacterial diversity was much higher in the continuouscropping soils than in $1 \mathrm{H}$ (Supplementary Figure 2). This finding was in line with the results of Liu et al. (2020b), who found that soybean continuously cropped for 13 years increased the diversity of soil bacterial communities. An increased soil microbial diversity was found to be responsible for the suppression of soil-borne plant diseases (Mazzola, 2004; Shen et al., 2018). However, in this study, there was no significant difference in bacterial diversity between the diseased and healthy soils. Analysis using PREMANOVA showed that the effect of continuous cropping on the bacterial community structure was stronger than that of the disease factor. This indicated that after long-term continuous ginger mono-cropping, the impact of disease on microorganisms was no longer the main factor.

\section{Possible Roles of PGPRs in Alleviating Continuous Cropping Obstacles and} Aluminum Stress

PGPRs have the potential to ensure plant health under stressful conditions (Nadeem et al., 2015). PGPRs colonize the root surface and rhizospheres, where they compete with pathogenic organisms for nutrients and space (Faina et al., 2010) and/or prevent the proliferation of plant pathogens through the synthesis of different antibiotics (Compant et al., 2005). Multiple Bacillus and Paenibacillus spp. can promote crop health, suppress plant pathogens by producing antibiotic metabolites, or directly stimulate plant host defenses prior to infection in a variety of ways (Gardener, 2004). Pseudomonas fluorescens, which belongs to the genus Pseudomonas, is a widely used antagonistic antibacterial agent for controlling bacterial wilt (Anith et al., 2000; Ran et al., 2005), and it can also inhibit the production 
of soil soluble $\mathrm{Al}$ and exchangeable $\mathrm{Al}$ (Nkoh et al., 2020). In contrast, Paenibacillus is suitable for growth in neutral environments (Liu et al., 2016; Kong et al., 2020) and may possess weak tolerance to aluminum toxicity. She et al. demonstrated that the abundance of Arthrobacter had a significant negative correlation with tobacco bacterial wilt disease after long-term continuous cropping (She et al., 2016).

The organic acids released from plant roots, such as malic acid, oxalic acid, and citric acid, can chelate $\mathrm{Al}$ ions, reducing the toxicity of Al to plants (Kochian et al., 2015). Malic acid can attract beneficial bacteria such as Bacillus to colonize the rhizosphere of plants, thereby enhancing plant resistance (Rudrappa et al., 2008). Al-tolerant bacteria (e.g., Serratia) in soil

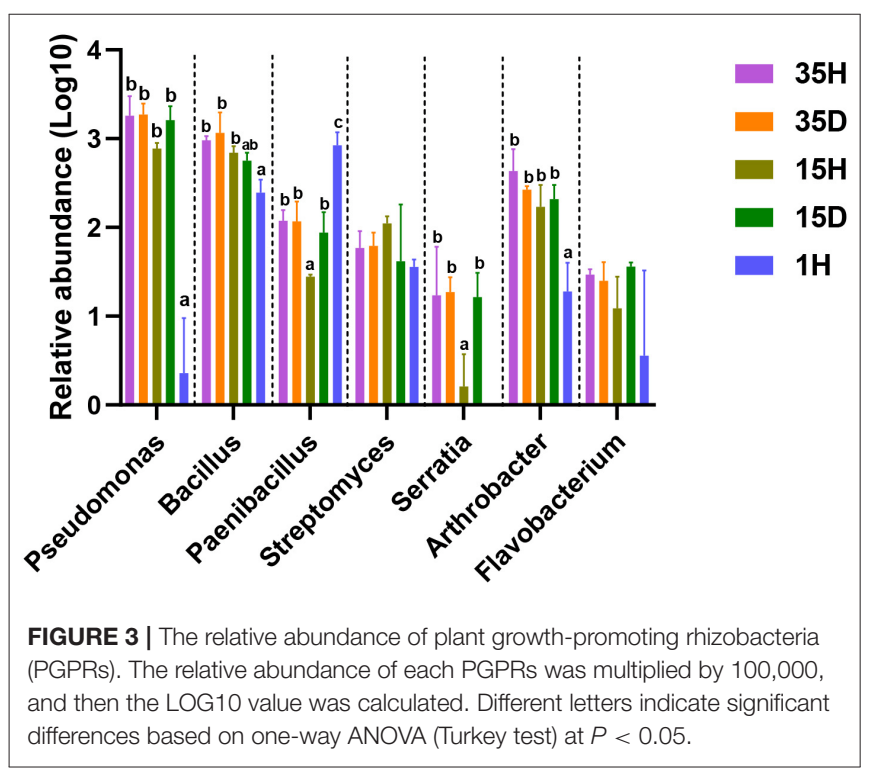

could form $\mathrm{Al}^{3+}$-siderophore complexes and promote $\mathrm{P}$ uptake to alleviate Al phytotoxicity (Mora et al., 2017). Also, Al-resistant plant cultivars can recruit beneficial microbes to alleviate the stresses (Shi et al., 2020).

Strains belonging to Bacillus, Pseudomonas, and Serratia have also been used as PGPRs for ginger growth promotion and biocontrol (Dinesh et al., 2015). Arthrobacter can both enhance ginger growth and inhibit ginger bacterial wilt (Zhang et al., 2018). Bacillus has been extensively studied for growth promotion and the suppression of bacterial wilt caused by Ralstonia solanacearum (Hyakumachi et al., 2013; Shiyong et al., 2013). Bacillus, as a ginger rhizosphere growthpromoting bacteria, provides effective protection to ginger rhizomes (Jimtha John et al., 2016) and exerts a substantial inhibitory effect on ginger soil-borne diseases, such as rhizome rot (Zhang N. et al., 2017) and bacterial wilt (Yang et al., 2012). In this study, after long-term continuous cropping, the relative abundances of Pseudomonas, Bacillus, Serratia, and Arthrobacter in the rhizosphere soil of ginger increased significantly (Figure 3). Interestingly, Bacillus had an extremely significantly positive correlation (Spearman, $r=0.670, P$ $=0.006)$ with aluminum ions, and $\mathrm{Ca}^{2+} / \mathrm{Al}^{3+}, \mathrm{Mg}^{2+} / \mathrm{Al}^{3+}$, and $\mathrm{Ca}^{2+} /\left(\mathrm{Ca}^{2+}+\mathrm{Fe}^{3+}+\mathrm{Al}^{3+}\right)$ had extremely significantly negative correlations with Pseudomonas, Bacillus, Arthrobacter, and Serratia in all soil samples (Supplementary Table 2). Furthermore, Pseudomonas and Bacillus were significantly positively correlated with aluminum ions, and $\mathrm{Ca}^{2+} / \mathrm{Al}^{3+}$, $\mathrm{Mg}^{2+} / \mathrm{Al}^{3+}$, and $\mathrm{Ca}^{2+} /\left(\mathrm{Ca}^{2+}+\mathrm{Fe}^{3+}+\mathrm{Al}^{3+}\right)$ had extremely significantly negative correlations with Pseudomonas, Bacillus, Arthrobacter, and Serratia in the healthy soils (Table 2). These results indicated that the increase of PGPRs, especially Bacillus, Pseudomonas, Arthrobacter, and Serratia, may be an important factor in relieving continuous cropping obstacles and preventing the occurrence of ginger bacterial wilt under stressful aluminum conditions.

TABLE 2 | Correlation coefficients (Spearman) between aluminum toxicity index and the PGPRs in healthy and diseased soil.

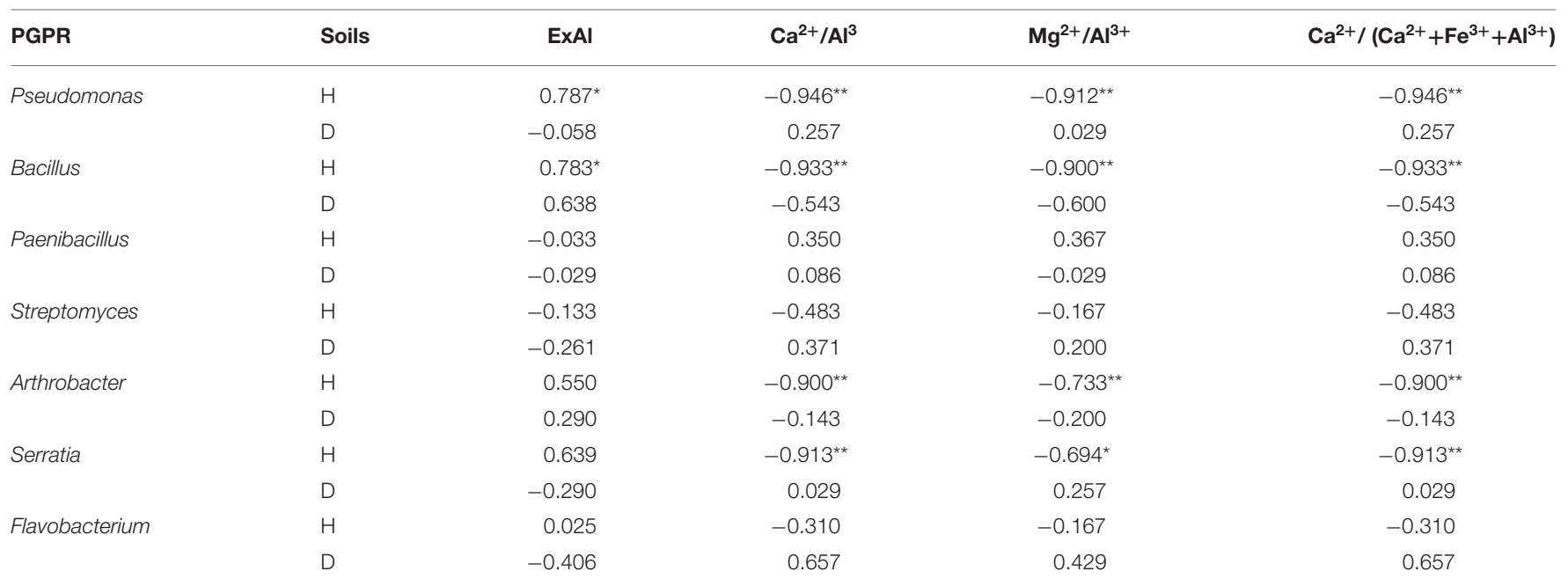

$H$, healthy soils; D, diseased soils. "Indicated P-values below 0.05, "Indicated P-values below 0.01. 
With the increase in continuous cropping years, the soil bacterial community structure changed significantly. The aluminum toxicity of diseased soil was significantly higher than that of healthy soil. In the diseased ginger soil, $\mathrm{pH}$ decreased and the aluminum toxicity increased significantly. In the healthy soil with a long continuous cropping duration, the abundance of ginger growth promoting rhizobacteria (PGPRs), such as Bacillus, Pseudomonas, Arthrobacter, and Serratia, was relatively higher than that of diseased soil, and these potential PGPRs had a significant positive correlation with aluminum toxicity in the healthy soil with a long continuous cropping period. These results indicated that continuous cropping was the main factor affecting the microbial community structure, and aluminum toxicity was a main factor affecting the occurrence of bacterial wilt in extremely acidic soil, and ginger can alleviate aluminum toxicity by stimulating the increase of PGPRs in a long-term aluminum stress environment, thereby reducing the occurrence of ginger bacterial wilt.

\section{DATA AVAILABILITY STATEMENT}

The datasets generated for this study can be found in online repositories. The names of the repository/repositories

\section{REFERENCES}

Anith, K. N., Manomohandas, T. P., Jayarajan, M., Vasanthakumar, K., and Aipe, K. C. (2000). Integration of soil solarization and biological control with a fluorescent Pseudomonas sp. for controlling bacterial wilt Ralstonia solanacearum (E. F. Smith) Yabuuchi et al. of ginger. J. Biol. Cont. 14, 25-29. doi: $10.18311 / \mathrm{jbc} / 2000 / 4020$

Baba, M., and Okazaki, M. (2000). Changes in aluminum pools of andisols due to soil acidification. Soil Sci. Plant Nutr. 46, 797-805. doi: 10.1080/00380768.2000.10409145

Bojorquez-Quintal, E., Escalante-Magana, C., Echevarria-Machado, I., and Martinez-Estevez, M. (2017). Aluminum, a friend or foe of higher plants in acid soils. Front. Plant Sci. 8:1767. doi: 10.3389/fpls.2017.01767

Bruggen, A. H. C. V., and Semenov, A. M. (2000). In search of biological indicators for soil health and disease suppression. Appl. Soil Ecol. 15, 0-24. doi: 10.1016/S0929-1393(00)00068-8

Caporaso, J. G., Kuczynski, J., Stombaugh, J., Bittinger, K., Bushman, F. D., Costello, E. K., et al. (2010). QIIME allows analysis of highthroughput community sequencing data. Nat. Methods 7, 335-336. doi: 10.1038/nmeth.f.303

Choudhary, D. K., Anil, P., and Johri, B. N. (2007). Induced systemic resistance (ISR) in plants: mechanism of action. Indian J. Microbiol. 47, 289-297. doi: 10.1007/s12088-007-0054-2

Compant, S., Duffy, B., J., Clement, C., and Barka, E. A. (2005). Use of plant growth-promoting bacteria for biocontrol of plant diseases: principles, mechanisms of action, and future prospects. Appl. Environ. Microbiol. 71, 4951-4959. doi: 10.1128/AEM.71.9.4951-4959.2005

Dinesh, R., Anandaraj, M., Kumar, A., Bini, Y. K., Subila, K. P., and Aravind, R. (2015). Isolation, characterization, and evaluation of multi-trait plant growth promoting rhizobacteria for their growth promoting and disease suppressing effects on ginger. Microbiol. Res. 173, 34-43. doi: 10.1016/j.micres.2015. 01.014

Dong, D., Xie, Z., Du, Y., Wang, C. L., and Shengtian. (1999). Influence of soil ph on aluminum availability in the soil and aluminum in tea leaves. Commun. Soil Sci. Plant Anal. 30, 873-883. doi: 10.1080/00103629909370252

Faina, K., Shamil, V., Tatiyana, A., Ine, M., and Ben, L. (2010). Enrichment for enhanced competitive plant root tip colonizers selects for a and accession number(s) can be found in the article/Supplementary Material.

\section{AUTHOR CONTRIBUTIONS}

WD and SZ designed the experiments. SZ, QJ, and LL performed the experiments and collected the data. SZ and XL analyzed the data. SZ wrote the manuscript. QJ, XL, LL, and WD edited and commented on the manuscript. All authors contributed to the article and approved the submitted version.

\section{ACKNOWLEDGMENTS}

This work was supported by the project of Chongqing Technology Innovation and Application (cstc2018jscxmszdX0047).

\section{SUPPLEMENTARY MATERIAL}

The Supplementary Material for this article can be found online at: https://www.frontiersin.org/articles/10.3389/fmicb. 2020.569512/full\#supplementary-material new class of biocontrol bacteria. Environ. Microbiol. 7, 1809-1817. doi: 10.1111/j.1462-2920.2005.00889.x

Gardener, B. (2004). Ecology of Bacillus and Paenibacillus spp. in agricultural systems. Phytopathology 94, 1252-1258. doi: 10.1094/PHYTO.2004.94.11.1252

Guo, J. H., Qi, H. Y., Guo, Y. H., Ge, H. L., Gong, L. Y., Zhang, L. X., et al. (2004). Biocontrol of tomato wilt by plant growth-promoting rhizobacteria. Biol. Control 29, 66-72. doi: 10.1016/S1049-9644(03)00124-5

Hyakumachi, M., Nishimura, M., Arakawa, T., Asano, S., Yoshida, S., Tsushima, S., et al. (2013). Bacillus thuringiensis suppresses bacterial wilt disease caused by Ralstonia solanacearum with systemic induction of defense-related gene expression in tomato. Microb. Environ. 28, 128-134. doi: 10.1264/jsme2.ME12162

Islam, A. K. M. S., Edwards, D. G., and Asher, C. J. (1980). pH optima for crop growth: results of a flowing solution culture experiment with six species. Plant Soil 54, 339-357. doi: 10.1007/BF02181830

Jimtha John, C., Jishma, P., Arathy, G. B., Anisha, C., and Radhakrishnan, E. K. (2016). Identification of plant growth promoting Rhizosphere Bacillus sp. WG4 antagonistic to Pythium myriotylum and its enhanced antifungal effect in association with Trichoderma. J. Soil Sci. Plant Nutr. 16, 578-590. doi: 10.4067/S0718-95162016005000026

Kazda, M., and Zvacek, L. (1989). Aluminium and manganese and their relation to calcium in soil solution and needles in three Norway spruce (Picea abies, L. Karst.) stands of Upper Austria. Plant Soil 114, 257-267. doi: 10.1007/BF02220806

Kochian, L. V., Hoekenga, O. A., and Pineros, M. A. (2004). How do crop plants tolerate acid soils? Mechanisms of aluminum tolerance and phosphorous efficiency. Annu. Rev. Plant Biol. 55, 459-493. doi: 10.1146/annurev.arplant.55.031903.141655

Kochian, L. V., Pineros, M. A., Liu, J., and Magalhaes, J. V. (2015). Plant adaptation to acid soils: the molecular basis for crop aluminum resistance. Annu. Rev. Plant Biol. 66, 571-598. doi: 10.1146/annurev-arplant-043014-114822

Kochian, V. L. (1995). Cellular mechanisms of aluminum toxicity and resistance in plants. Ann. Rev. Plant Physiol. Plant Mol. Biol. 46, 237-260. doi: 10.1146/annurev.pp.46.060195.001321

Kong, D., Zhang, Q., Jiang, X., Ma, Q., Han, X., Zhou, Y., et al. (2020). Paenibacillus solisilvae sp. nov., isolated from birch forest soil. Int. J. Syst. Evol. Microbiol. 70:e004093. doi: 10.1099/ijsem.0.004093 
Labanca, E. R. G., Andrade, S. A. L., Kuramae, E. E., and Silveira, A. P. D. (2020). The modulation of sugarcane growth and nutritional profile under aluminum stress is dependent on beneficial endophytic bacteria and plantlet origin. Appl. Soil Ecol. 156:103715. doi: 10.1016/j.apsoil.2020.103715

Li, H., Huang, M., Tan, D., Liao, Q., Yong, Z., and Jiang, Y. (2018). Effects of soil moisture content on the growth and physiological status of ginger (Zingiber officinale Roscoe). Acta Physiol. Plant. 40:125. doi: 10.1007/s11738-018-2698-4

Li, J., and Dong, Y. (2013). Effect of a rock dust amendment on disease severity of tomato bacterial wilt. Antonie Van Leeuwenhoek 103, 11-22. doi: 10.1007/s10482-012-9781-4

Li, S., Liu, Y., Wang, J., Yang, L., Zhang, S., Xu, C., et al. (2017). Soil acidification aggravates the occurrence of bacterial wilt in South China. Front. Microbiol. 8:703. doi: 10.3389/fmicb.2017.00703

Liu, B., Liu, G. H., Sengonca, C., Schumann, P., Lan, J. L., Chen, D. J., et al. (2016). Paenibacillus solani sp. nov., isolated from potato rhizosphere soil. Int. J. Syst. Evol. Microbiol. 66, 4486-4491. doi: 10.1099/ijsem.0.001378

Liu, B., Luo, C., Li, X., Gray, L., Fan, Z., Mu, L., et al. (2014a). Research on the threshold of aluminum toxicity and the alleviation effects of exogenous calcium, phosphorus, and nitrogen on the growth of chinese fir seedlings under aluminum stress. Commun. Soil Sci. Plant Anal. 45, 126-139. doi: 10.1080/00103624.2013.841917

Liu, H., Brettell, L. E., Qiu, Z., and Singh, B. K. (2020a). Microbiomemediated stress resistance in plants. Trends Plant Sci. 25, 733-743. doi: 10.1016/j.tplants.2020.03.014

Liu, X., Zhang, J., Gu, T., Zhang, W., Shen, Q., Yin, S., et al. (2014b). Microbial community diversities and taxa abundances in soils along a seven-year gradient of potato monoculture using high throughput pyrosequencing approach. PLoS ONE 9:e0086610. doi: 10.1371/journal.pone.0086610

Liu, Z., Liu, J., Yu, Z., Yao, Q., Li, Y., Liang, A., et al. (2020b). Long-term continuous cropping of soybean is comparable to crop rotation in mediating microbial abundance, diversity and community composition. Soil Tillage Res. 197:104503. doi: 10.1016/j.still.2019.104503

Lugtenberg, B., and Kamilova, F. (2009). Plant-growthpromoting rhizobacteria. Annu. Rev. Microbiol. 2009, 541-556. doi: 10.1146/annurev.micro.62.081307.162918

Luo, C. (2000). Researches on the threshold of aluminum toxicity and the decline of Chinese fir plantation in hilly area around the Sichuan basin. Scientia Silvae Sinicae. 36, 9-14. doi: 10.11707/j.1001-7488.20000102

Massot, N., Llugany, M., Poschenrieder, C., and Barceló J. (1999). Callose production as indicator of aluminum toxicity in bean cultivars. J. Plant Nutr. 22, 1-10. doi: 10.1080/01904169909365601

Mazzola, M. (2004). Assessment and management of soil microbial community structure for disease suppression. Annu. Rev. Phytopathol. 42, 35-59. doi: 10.1146/annurev.phyto.42.040803.140408

Ming, L., Min, Z., Ji, J., Yin, F., Yu, Z., Yong, T., et al. (2005). Advances in research bacterial wilt of ginger in China. Chin. Agric. Sci. Bull. 21, 337-340.

Mora, M. D. L., Demanet, R., Acuña, J. J., Viscardi, S., Jorquera, M., Rengel, Z., et al. (2017). Aluminum-tolerant bacteria improve the plant growth and phosphorus content in ryegrass grown in a volcanic soil amended with cattle dung manure. Appl. Soil Ecol. 115, 19-26. doi: 10.1016/j.apsoil.2017.03.013

Nadeem, S. M., Naveed, M., Ahmad, M., and Zahir, Z. A. (2015). "Rhizosphere bacteria for crop production and improvement of stress tolerance: mechanisms of action, applications, and future prospects," in Plant Microbes Symbiosis: Applied Facets, ed N. K. Arora (New Delhi: Springer), 1-36. doi: 10.1007/978-81-322-2068-8_1

Niu, D. D., Liu, H. X., Jiang, C. H., Wang, Y. P., Wang, Q. Y., Jin, H. L., et al. (2011). The plant growth-promoting rhizobacterium Bacillus cereus AR156 induces systemic resistance in Arabidopsis thaliana by simultaneously activating salicylate- and jasmonate/ethylene-dependent signaling pathways. Mol. Plant Microbe. Interact. 24, 533-542. doi: 10.1094/MPMI-09-10-0213

Nkoh, J. N., Yan, J., Xu, R. K., Shi, R. Y., and Hong, Z. N. (2020). The mechanism for inhibiting acidification of variable charge soils by adhered Pseudomonas fluorescens. Environ. Pollut. 260:114049. doi: 10.1016/j.envpol.2020.114049

Olivares, E., Pen, A. E., Marcano, E., Mostacero, J., Aguiar, G., Benítez, M., et al. (2009). Aluminum accumulation and its relationship with mineral plant nutrients in 12 pteridophytes from Venezuela. Environ. Exp. Bot. 65, 132-141. doi: 10.1016/j.envexpbot.2008.04.002
Pietri, J. C. A., and Brookes, P. C. (2008). Relationships between soil pH and microbial properties in a UK arable soil. Soil Biol. Biochem. 40, 1856-1861. doi: 10.1016/j.soilbio.2008.03.020

Raj, S. N., Deepak, S. A., Basavaraju, P., Shetty, H. S., Reddy, M. S., and Kloepper, J. W. (2003). Comparative performance of formulations of plant growth promoting rhizobacteria in growth promotion and suppression of downy mildew in pearl millet. Crop Protect. 22, 579-588. doi: 10.1016/S0261-2194(02)00222-3

Ran, L. X., Liu, C. Y., Wu, G. J., Loon, L. C. V., and Bakker, P. A. H. M. (2005). Suppression of bacterial wilt in Eucalyptus urophylla by fluorescent Pseudomonas spp. in China. Biol. Control 32, 111-120. doi: 10.1016/j.biocontrol.2004.08.007

Rehmus, A., Bigalke, M., Valarezo, C., Castillo, J. M., and Wilcke, W. (2014). Aluminum toxicity to tropical montane forest tree seedlings in southern Ecuador: response of biomass and plant morphology to elevated $\mathrm{Al}$ concentrations. Plant Soil 382, 301-315. doi: 10.1007/s11104-014-2110-0

Rousk, J., Baath, E., Brookes, P. C., Lauber, C. L., Lozupone, C., Caporaso, J. G., et al. (2010). Soil bacterial and fungal communities across a $\mathrm{pH}$ gradient in an arable soil. ISME J. 4, 1340-1351. doi: 10.1038/ismej.2010.58

Rudrappa, T., Czymmek, K. J., Pare, P. W., and Bais, H. P. (2008). Root-secreted malic acid recruits beneficial soil bacteria. Plant Physiol. 148, 1547-1556. doi: 10.1104/pp.108.127613

Schmitt, M., Watanabe, T., and Jansen, S. (2016). The effects of aluminium on plant growth in a temperate and deciduous aluminium accumulating species. Aob Plants 8:plw065. doi: 10.1093/aobpla/plw065

She, S., Niu, J., Zhang, C., Xiao, Y., Chen, W., Dai, L., et al. (2016). Significant relationship between soil bacterial community structure and incidence of bacterial wilt disease under continuous cropping system. Arch. Microbiol. 199, 267-275. doi: 10.1007/s00203-016-1301-X

Shen, G., Zhang, S., Liu, X., Jiang, Q., and Ding, W. (2018). Soil acidification amendments change the rhizosphere bacterial community of tobacco in a bacterial wilt affected field. Appl. Microbiol. Biotechnol. 102, 9781-9791. doi: 10.1007/s00253-018-9347-0

Shi, Q., Jin, J., Liu, Y., Zhang, Y., Cai, Z., Ma, Q., et al. (2020). High aluminum drives different rhizobacterial communities between aluminumtolerant and aluminum-sensitive wild soybean. Front. Microbiol. 11:1996. doi: 10.3389/fmicb.2020.01996

Shipton, J. P. (1977). Monoculture and soilborne plant pathogens. Annu. Rev. Phytopathol. 15, 387-407. doi: 10.1146/annurev.py.15.090177.002131

Shiyong, T., Yue, D., Hanpeng, L., Jianfeng, H., Song, S., Yangchun, X., et al. (2013). Antagonistic bacterium Bacillus amyloliquefaciens induces resistance and controls the bacterial wilt of tomato. Pest Manag. Sci. 69, 1245-1252. doi: $10.1002 /$ ps.3491

Silva, S., Santos, C. O., Matos, M., and Pinto-Carnide, O. (2012). Al toxicity mechanism in tolerant and sensitive rye genotypes. Environ. Exp. Bot. 75, 89-97. doi: 10.1016/j.envexpbot.2011.08.017

Singh, S., Tripathi, D. K., Singh, S., Sharma, S., Dubey, N. K., Chauhan, D. K., et al. (2017). Toxicity of aluminium on various levels of plant cells and organism: a review. Environ. Exp. Bot. 137, 177-193. doi: 10.1016/j.envexpbot.2017. 01.005

Tahat, M. M., and Kamaruzaman, S. (2010). Ralstoina solanacearum: the bacterial wilt causal agent. Asian J. Plant Sci. 9, 385-393. doi: 10.3923/ajps.2010. 385.393

Vitorello, V. A., Capaldi, F. R., and Stefanuto, V. A. (2005). Recent advances in aluminum toxicity and resistance in higher plants. Braz. J. Plant Physiol. 17, 129-143. doi: 10.1590/S1677-04202005000100011

Wit, H. A. D., Mulder, J., Nygaard, P. H., and Dan, A. (2001). Testing the aluminium toxicity hypothesis: a field manipulation experiment in mature spruce forest in Norway. Water Air Soil Pollut. 130, 995-1000. doi: 10.1023/A:1013939725573

Xu, H. B., Zhao, D. Y., Qin, C., Li, Y. J., and Dong, C. X. (2014). Aluminum dissolution and changes of $\mathrm{pH}$ in soil solution during sorption of copper by aggregates of paddy soil. Huanjing Kexue 35, 248-253. doi: 10.13227/j.hjkx.2014.01.036

Xu, N., Tan, G., Wang, H., and Gai, X. (2016). Effect of biochar additions to soil on nitrogen leaching, microbial biomass and bacterial community structure. Eur. J. Soil Biol. 74, 1-8. doi: 10.1016/j.ejsobi.2016.02.004 
Xu, R. K., and Ji, G. L. (1998). Influence of $\mathrm{pH}$ on dissolution of aluminum in acid soils and the distribution of aluminum ion species. Acta Pedologica Sinica $35,162-171$.

Yang, W., Xu, Q., Liu, H.-X., Wang, Y.-P., Wang, Y.-M., Yang, H.-T., et al. (2012). Evaluation of biological control agents against Ralstonia wilt on ginger. Biol. Control 62, 144-151. doi: 10.1016/j.biocontrol.2012. 05.001

Zhalnina, K., Dias, R., de Quadros, P. D., Davis-Richardson, A., Camargo, F. A., Clark, I. M., et al. (2015). Soil pH determines microbial diversity and composition in the park grass experiment. Microb. Ecol. 69, 395-406. doi: 10.1007/s00248-014-0530-2

Zhang, J., Guo, T., Wang, P., Tian, H., Wang, Y., and Cheng, J. (2018). Characterization of diazotrophic growth-promoting rhizobacteria isolated from ginger root soil as antagonists against Ralstonia solanacearum. Biotechnol. Biotechnol. Equip. 32, 1447-1454. doi: 10.1080/13102818.2018. 1533431

Zhang, N., Pan, R., Shen, Y., Yuan, J., Wang, L., Luo, X., et al. (2017). Development of a novel bio-organic fertilizer for plant growth promotion and suppression of rhizome rot in ginger. Biol. Control 114, 97-105. doi: 10.1016/j.biocontrol.2017.08.001
Zhang, S., Liu, X., Jiang, Q., Shen, G., and Ding, W. (2017). Legacy effects of continuous chloropicrin-fumigation for 3-years on soil microbial community composition and metabolic activity. $A M B$ Express 7:178. doi: 10.1186/s13568-017-0475-1

Zhou, G., Delhaize, E., Zhou, M., and Ryan, P. R. (2011). Biotechnological Solutions for Enhancing the Aluminium Resistance of Crop Plants. Abiotic Stress in Plants - Mechanisms and Adaptations. InTech. 119-142. doi: $10.5772 / 25187$

Conflict of Interest: The authors declare that the research was conducted in the absence of any commercial or financial relationships that could be construed as a potential conflict of interest.

Copyright $\odot 2020$ Zhang, Jiang, Liu, Liu and Ding. This is an open-access article distributed under the terms of the Creative Commons Attribution License (CC BY). The use, distribution or reproduction in other forums is permitted, provided the original author(s) and the copyright owner(s) are credited and that the original publication in this journal is cited, in accordance with accepted academic practice. No use, distribution or reproduction is permitted which does not comply with these terms. 